\title{
CDISC SDTM Skin Type Terminology
}

National Cancer Institute

\section{Source}

National Cancer Institute. CDISC SDTM Skin Type Terminology. NCI Thesaurus. Code C74561.

Terminology codelist used for Skin Type within the Clinical Data Interchange Standards Consortium Study Data Tabulation Model. 